\title{
REDESAIN PASAR KOPRO MENJADI PASAR BERBASIS NOL SAMPAH MAKANAN, GROGOL PETAMBURAN
}

\author{
Venny Mettasari ${ }^{1)}$, Petrus Rudi Kasimun ${ }^{2)}$
}

1)Program Studi S1 Arsitektur, Fakultas Teknik, Universitas Tarumanagara, venny.315170124@stu.untar.ac.id
2)Program Studi S1 Arsitektur, Fakultas Teknik, Universitas Tarumanagara, petrusk@ft.untar.ac.id

\begin{abstract}
Abstrak
Sampah makanan adalah salah satu isu ekologi yang terdapat pada kota-kota besar. Nyatanya, sampah makanan merupakan salah satu penyebab efek rumah kaca terbesar. Makanan yang dibuang, jika ditimbun dapat menghasilkan gas metana yang dapat merusak lapisan ozon yang dapat mengakibatkan pemanasan global. Menurut data sistem Informasi Pengelolaan Sampah Nasional KLHK tahun 2017-2018, komposisi sampah sisa makanan di Jakarta Barat merupakan yang tertinggi diantara daerah metropolitan lainnya dengan $70 \%$ komposisi dari sampah adalah sampah makanan. Oleh karena itu, diperlukannya penanganan agar sampah makanan dapat diolah agar bisa digunakan kembali. Program yang diusulkan memiliki tujuan untuk menciptakan siklus pasar berbasis nol sampah makanan yang diharapkan dapat mengurangi isu lingkungan tentang banyaknya sampah makanan yang terbuang khususnya di Kota Jakarta. Konsep yang digunakan adalah bangunan berkelanjutan yang menggunakan metode desain arsitektur hijau agar dapat mewadahi kegiatan masyarakat sehingga bangunan ini di desain memiliki ruang dalam yang semi terbuka dan menggunakan material yang ramah lingkungan. Program pasar ini pun didukung dengan beberapa program yang lainnya seperti program pengolahan, dan komunitas, dapur kecil, serta area makan. Pengelompokkan kegiatan dibuat berdasarkan zoning dan memperhatikan privasi dari setiap kegiatan. Dengan adanya bangunan ini diharapkan dapat mengurangi maraknya sampah makanan yang dapat meningkatkan pemanasan global.
\end{abstract}

Kata kunci: arsitektur hijau; pasar berbasis nol sampah makanan; pemanasan global; sampah makanan

\begin{abstract}
Food waste is one of the ecological issues that exist in big cities. In fact, food waste is one of the biggest causes of the greenhouse effect. Food that is thrown away, if stockpiled can produce methane gas which can destroy the ozone layer which can lead to global warming. According to data from the Ministry of Environment and Forestry's National Waste Management Information System for 2017-2018, the composition of food waste in West Jakarta is the highest among other metropolitan areas with $70 \%$ of the composition of waste is food waste. Therefore, the need for handling so that food waste can be processed so that it can be reused. The proposed program aims to create a market cycle based on zero food waste which is expected to reduce environmental issues regarding the amount of food waste that is wasted, especially in the city of Jakarta. The concept used is a sustainable building that uses green architectural design methods so that it can accommodate community activities so that this building is designed to have a semi-open inner space and uses environmentally friendly materials. This market program is also supported by several other programs such as processing and community programs, small kitchens, and dining areas. Activity grouping is made based on zoning and takes into account the privacy of each activity. With this building, it is hoped that it can reduce the increase in food waste which can increase global warming.
\end{abstract}

\section{Keywords: food waste; global warming, green architecture, zero food waste market}




\section{PENDAHULUAN}

\section{Latar Belakang}

Sampah makanan adalah salah satu isu ekologi yang terdapat pada kota-kota besar. Nyatanya sampah makanan merupakan salah satu penyebab efek rumah kaca terbesar. Makanan yang dibuang jika ditimbun dapat menghasilkan gas metana yang dapat merusak lapisan ozon selain merusak lapisan ozon, gas metana yang tertimbun dalam kuantitas besar dapat menghasilkan ledakan yang berbahaya (Ratmia Dewi, 2020). FAO menyatakan bahwa sekitar 33\% hingga 50\% makanan yang telah diproduksi, tidak dikonsumsi dengan semestinya. Makanan yang tidak terpakai oleh konsumen maupun oleh penjual padahal masih layak dimakan pun akan dibuang juga.

\section{Rumusan Permasalahan}

Dari latar belakang tersebut, terdapat beberapa masalah yang ditemukan dan dapat menjadi bahan penelitian, yang pertama adalah jumlah makanan yang terus meningkat secara signifikan. Yang kedua adalah kurang adanya rasa kepedulian warga terhadap lingkungan sekitar karena sampah makanan dapat meningkatkan pemanasan global. Dan yang ketiga adalah pandangan masyarakat terhadap sampah makanan hanya sebatas sebagai sampah saja sedangkan sampah makanan sebetulnya dapat diolah kembali.

\section{Tujuan}

Tujuan proyek rancangan ini adalah untuk menciptakan proyek arsitektur dengan sistem pangan berkelanjutan agar jumlah sampah makanan dapat ditekan. Selain itu untuk menciptakan pasar yang berkelanjutan/sustainable. Menjadikan pasar sebagai salah satu wilayah bebas sampah makanan juga merupakan salah satu tujuan dengan menyediakan wadah bagi aktivitas edukasi yang berkaitan dengan pangan/makanan. Serta meningkatkan peranan dalam perekonomian Jakarta.

\section{KAJIAN LITERATUR}

\section{Ekologi}

Ekologi adalah suatu ilmu yang mempelajari organisme yang ada disekitarnya. Ekologi mencakup beberapa satuan makhluk hidup atau organisme. Dalam ekologi terdapat hirarki yang dimulai dari tingkatan terkecil yaitu molekul, sel, jaringan, organ, sistem organ, individu, populasi, komunitas, ekosistem, dan biosfer. Terdapat komponen biotik atau hidup dan abiotik atau non hidup dalam ekologi dan seluruh komponen ini saling berinteraksi (Adiwibowo 2007).

\section{Teknik Pengolahan Sampah Rumah Tangga}

Pengolahan sampah bertujuan untuk meningkatkan 'kesehatan masyarakat dankualitas lingkungan serta menjadikan sampah sebagai sumber daya. Berikut merupakan beberapa cara pengolahan sampah dengan baik dan benar agar dapat digunakan kembali :

a. Digester Anerobic

Bakteri Anaerobik membutuhkan nutrisi sebagai sumber energi untuk proses reaksi anaerob seperti mineral-mineral yang mengadung Nitrogen, Fosfor, Magnesium, Sodium, Mangan, Kalsium, Kobalt. Nutrisi ini dapat bersifat toxic (racun) apabila konsentrasi di dalam bahan terlalu banyak. Proses pengolahan menggunakan metode Digester Anerobic merupakan salah satu cara yang cukup efektif untuk digunakan untuk mengolah sampah dan dapat menghasilkan output yang dapat digunakan kembali (lih. Gambar 1) 


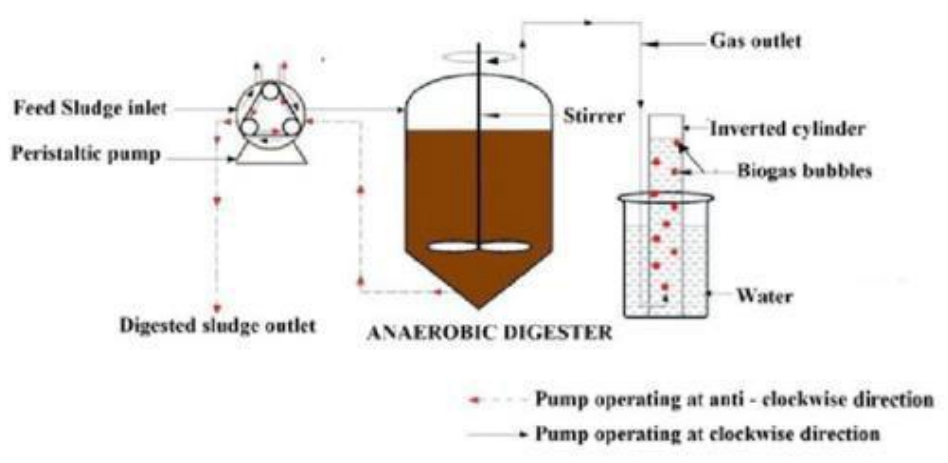

Gambar 1. Proses Pengolahan Digester Anerobic Sumber: Researchgate.com

b. Biogas

Menurut Wahyuni (2013), biogas adalah gas mudah terbakar yang dihasilkan dari proses penguraian bahan organik oleh bakteri yang hidup dalam kondisi kedap udara (bakteri anaerob) terhadap limbah-limbah organik baik di digester maupun di tempat pembuangan akhir sampah. Gas ini sering dimanfaatkan untuk pemanas, memasak, pembangkit listrik dan transportasi. (lih. gambar 2)

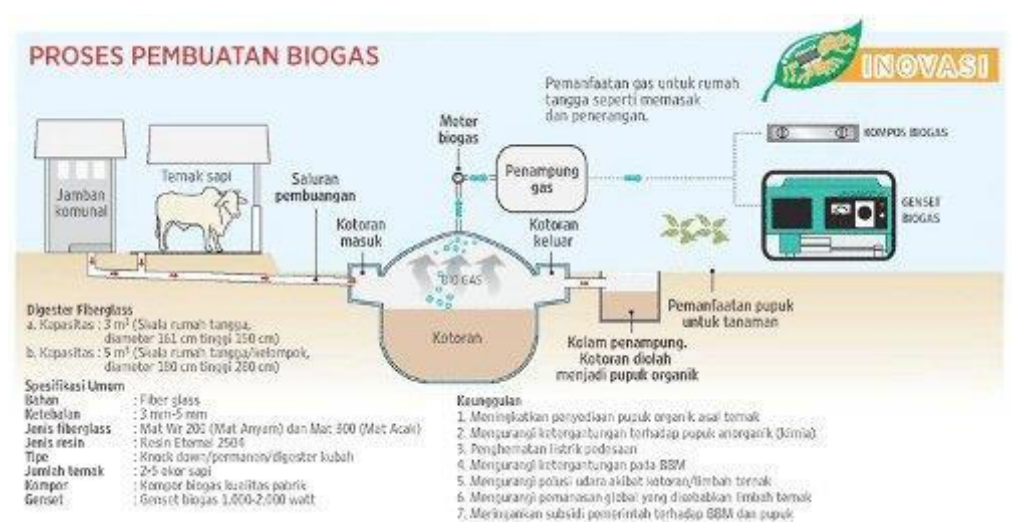

Gambar 2. Proses Pembuatan Biogas

Sumber: Lembaga Ilmu Pengetahuan Indonesia

\section{Pengertian Redesain}

Menurut kamus kata "Redesain" berasal dari bahasa inggris (redesign) yang terdiri dari dua kata yang digabungkan yaitu re dan design yang berarti "merancang ulang" atau "merancang ulang produk" dari produk yang sudah ada sebelumnya (KBBI, 2008). Bisa dikatakan bahwa redesain merupakan kegiatan merancang ulang sebuah desain dengan mengubah tampilan fisik saja, fungsi saja, ataupun mengubah bentuk fisik sekaligus fungsi untuk mencapai tujuan yang lebih baik (Nugroho, 2012).

\section{Redesain pada Pasar}

Berdasarkan pengertian redesain pada pembahasan sebelumnya, bisa dikatakan bahwa Redesain Pasar berarti merancang atau merencanakan ulang bangunan pasar yang sudah ada. Pada kasus kali ini bangunan yang di redesain adalah Pasar Niten. Perancangan ulang yang dilakukan berupa perubahan pada bentuk fisik dan beberapa perombakan pada fungsi. Hal ini dilakukan untuk menjawab isu yang ada salah satu nya adalah adanya wacana untuk menata ulang pasar dengan menggabungkan dua fungsi yaitu pasar utama dan pasar daur ulang. 


\section{METODE}

\section{Metode Penelitian}

Metode penelitian yang dilakukan adalah dengan pengumpulan data sekunder melalui literatur, jurnal, e-book, dan artikel website yang terkait dengan isu dan teori dalam perancangan. Penentuan dan analisis juga juga dilakukan secara digital, melalu Google Maps, Google Earth, berita dan jurnal yang memberikan informasi seputar tapak terpilih.

\section{Metode Desain}

Metode arsitektur hijau adalah metode yang digunakan dalam proses perancangan. Arsitektur hijau ini sendiri berusaha memberikan solusi terhadap permasalahan iklim di lingkungannya dan berusaha membuat bangunan yang melampaui ekologi. Bangunan ini juga berusaha menghemat energi, mereduksi emisi, meningkatkan produksi, meminimalisasi pengeluaran dan meningkatkan nilai tambah bangunan (Design media Publishings Limited, 2010); berkelanjutan, ramah lingkungan, tanggap iklim, sadar energi dan cerdas budaya (Nugroho, 2019).

Tabel 1. Kriteria Metode Desain

\begin{tabular}{|c|c|c|}
\hline No. & Indikator & Definisi \\
\hline 1. & $\begin{array}{l}\text { Sustainable } \\
\text { (Berkelanjutan) }\end{array}$ & $\begin{array}{l}\text { Bangunan green architecture / arsitektur hijau tetap bertahan dan } \\
\text { berfungsi seiring zaman, konsisten terhadap konsepnya yang } \\
\text { menyatu dengan alam tanpa adnya perubahan-perubahan yang } \\
\text { signifikan tanpa merusak alam sekitar. }\end{array}$ \\
\hline 2. & $\begin{array}{l}\text { Earthfriendly } \\
\text { (Ramah } \\
\text { Lingkungan) }\end{array}$ & $\begin{array}{l}\text { Suatu bangunan belum bisa dianggap sebagai bangunan berkonsep } \\
\text { green architecture apabila bangunan tersebut tidak bersifat ramah } \\
\text { lingkungan. Maksud tidak bersifat ramah lingkungan disini tidak } \\
\text { hanya dalam perusakkan terhadap lingkungan. Tetapi juga } \\
\text { menyangkut masalah pemakaian energi. Oleh karena itu bangunan } \\
\text { berkonsep green architecture mempunyai sifat ramah terhadap } \\
\text { lingkungan sekitar, energi, dan aspek-aspek pendukung lainnya. }\end{array}$ \\
\hline 3. & $\begin{array}{l}\text { High } \\
\text { Performance } \\
\text { Building }\end{array}$ & $\begin{array}{l}\text { Salah satu fungsi bangunan dengan sifat "High Performance Building" } \\
\text { adalah untuk meminimaliskan penggunaan energi dengan } \\
\text { memanfaatkan energi yang berasal dari alam (Energy of Nature) dan } \\
\text { dengan dipadukan dengan teknologi tinggi. Contohnya: } \\
\text { - Penggunaan panel surya untuk memanfaatkan energi panas } \\
\text { matahari sebagai sumber pembangkit tenaga listrik rumahan } \\
\text { - Penggunaan material-material yang dapat didaur ulang, } \\
\text { penggunaan konstruksi maupun bentuk fisik dan fasad bangunan } \\
\text { yang dapat mendukung konsep Green Architecture. }\end{array}$ \\
\hline
\end{tabular}

Sumber: Penulis, 2021

Metode perancangan desain arsitektur hijau tentunya harus memperhatikan 3 hal utama agar memenuhi kriteria, yaitu sustainable (berkelanjutan), earthfriendly (ramah lingkungan), dan high performance building. (lih. tabel 1).

\section{Data Primer}

Data primer dalam penelitian ini merupakan data lokasi proyek perancangan Pasar Kopro itu sendiri. Lokasi tersebut berada di Jalan Tanjung Duren Raya No. 14-15, RT 14/RW 05, Tanjung Duren Selatan, Grogol petamburan, Kota Jakarta Barat yang sekarang merupakan Pasar Kopro yang lama dan sudah layak di redesain. Peneliti akan mengambil langsung data ke lokasi proyek untuk mendapatkan informasi lingkungan sekitar, batasan wilayah, dan kondisi. Selanjutnya data ini akan menjadi bahan analisa dalam penelitian untuk menentukan zoning program dalam tapak serta kebutuhan luasan masing-masing program proyek perancangan. 
Data Sekunder

1. Syarat alur sistem pasar

Memerlukan informasi syarat pasar yang paling dasar apa saja. Bagaimana suatu tempat layak dapat dikatakan sebagai pasar, dapat ditinjau juga dari kondisi keadaan masyarakat sekitar serta tingkat perekonomiannya

\section{Kebutuhan kapasitas lahan pedagang}

Jumlah lahan pedagang/kios pedagang tentunya tidak boleh berkurang dari jumlah sebelum di redesain karena itu merupakan salah satu pertimbangan dalam menentukan kebutuhan kapasitas lahan pedagang. Tentunya harus ditentukan area per tipe jenis produk jualannya, seperti area daging dan ikan, sayur dan buah, fresh market, area bahan makanan sisa, dll. Hal ini bertujuan agar sistem pendistribusian sampah sisa dari masing-masing lahan pedagang dapat didistribusikan ke area pengolahan dengan baik dan tidak tercampur satu dengan yang lainnya karena jika tercampur, dapat menyebabkan salah satu jenis sampah dapat terkontaminasi dan hal ini berefek kepada umur masa sampah sampai sebelum dia sudah tidak layak dipakai.

3. Produksi sampah rata-rata dari setiap pedagang per hari nya

Perhitungan jumlah kapasitas mesin pengolahan sampah juga menjadi salah satu pertimbangan yang cukup vital karena pengolahan didalam proyek perancangan harus mampu menampung keseluruhan jumlah sampah didalam proyek perancangan. Pengolahan dalam tapak perancangan juga harus mampu menampung jumlah sampah melebihi jumlah produksi sampah dalam proyek perancangan itu sendiri. Hal ini tentunya bertujuan agar proyek perancangan dapat berdampak bukan hanya ke dalam proyek itu sendiri saja, melainkan masyarakat sekitar juga dapat merasakan dampak positif dari sistem Pasar Kopro yang baru ini.

\section{DISKUSI DAN HASIL}

\section{Konsep Arsitektur Hijau}

Perancangan proyek ini bertujuan untuk me-redesain Pasar Kopro yang berada di Grogol Petamburan, Jakarta Barat. Tujuan yang kedua adalah agar terciptanya mekanisme alur sampah makanan dalam proyek perancangan berupa siklus yang tertutup sehingga dapat menerapkan zero food waste. Dengan adanya siklus ini diharapkan dapat mengurangi jumlah sampah organik/makanan yang terbuang serta dapat meningkatkan ekonomi warga sekitar Pasar Kopro.

Pada bangunan pasar eksisting, bangunan terlihat belum ramah lingkungan karena bentuk bangunan yang cenderung masif dan tertutup membuat lingkungan pasar menjadi lingkungan yang tidak sehat. Karena itu diusulkan bangunan redesain pasar menggunakan metode arsitektur hijau agar bangunan menjadi lebih sehat dan sirkulasi udara menjadi lebih baik.

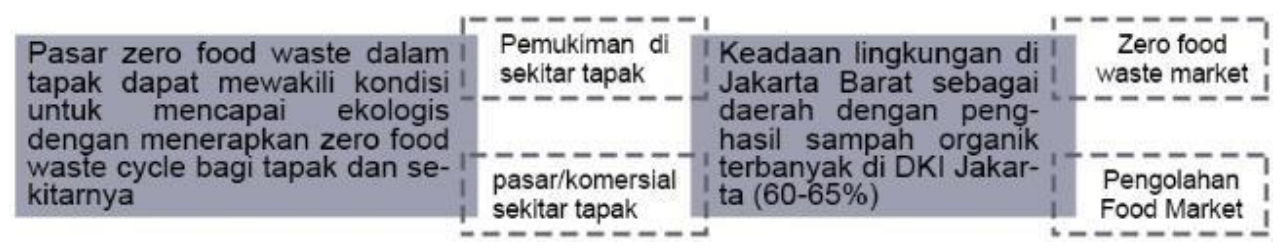

Gambar 3. Diagram Konsep Arsitektur Hijau

Sumber: Penulis, 2021

Metode green architecture atau arsitektur hijau ini sendiri dapat juga disebut sebagai arsitektur ekologis atau arsitektur ramah lingkungan. Metode ini merupakan salah satu pendekatan desain dan pembangunan yang didasarkan atas prinsip-prinsip ekologis dan konservasi lingkungan, 
yang akan menghasilkan satu karya bangunan yang mempunyai kualitas lingkungan dan menciptakan kehidupan yang lebih baik dan berkelanjutan. (lih. gambar 3). Pada bangunan redesain (lih. gambar 7), bangunan menjadi lebih hidup dan terbuka serta sudah diterapkan metode arsitektur hijau seperti membuat bangunan menjadi berkelanjutan dengan mengadakan program pengolahan yang hasil output nya dapat digunakan kembali. Bangunan yang sudah di redesain juga sudah menjadi bangunan ramah lingkungan karena menggunakan energi alam secara maksimal (pencahayaan, pengudaraan) agar tidak menggunakan banyak energi yang tidak baik bagi lingkungan.

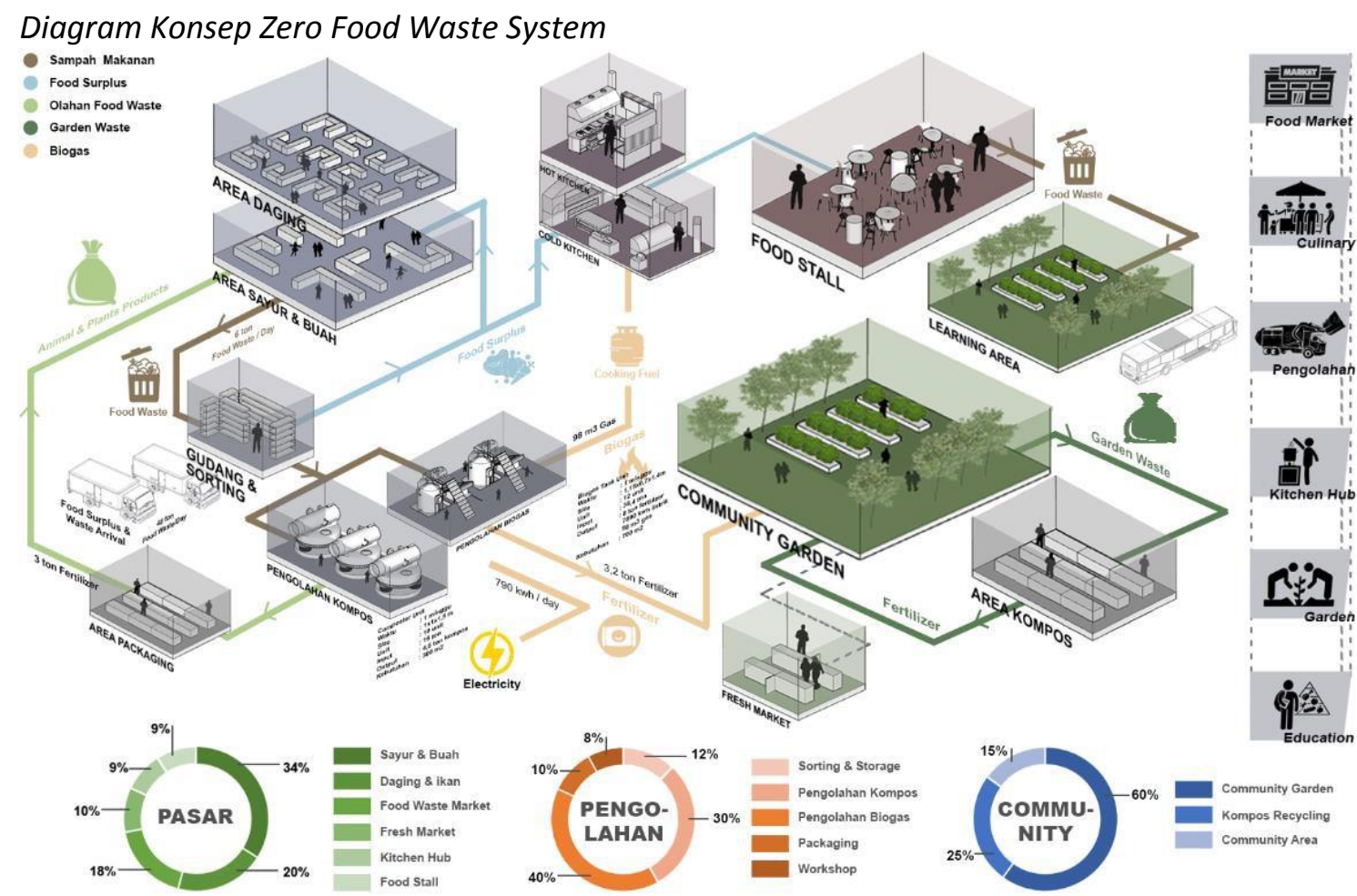

Gambar 4. Diagram Konsep Sistem Zero Food Waste

Sumber: Penulis, 2021

Diagram diatas merupakan konsep sistem mekanisme alur sampah makanan yang diterapkan dalam proyek perancangan bangunan berupa sistem yang tertutup sehingga zero food waste system dapat diterapkan dalam proyek perancangan. (lih. gambar 4).

Sampah makanan yang berasal dari pasar itu sendiri disatukan dengan sampah yang berasal dari luar pasar dan dikumpulkan didalam gudang penyimpanan yang akan disortir kembali berdasarkan masing- masing tipe jenis sampahnya itu sendiri. Setelah disortir, sampah akan diolah melalui 2 jenis tipe pengolahan yaitu pengolahan biogas dan pengolahan kompos. Setelah diolah yang menggunakan teknik pengolahan biogas, output yang dihasilkan adalah listrik, gas untuk memasak, dan fertilizer yang akan digunakan pada community garden. Gas untuk memasak akan digunakan pada kitchen hub yang hasil makanannya akan dijual pada food stall dengan harga yang terjangkau karena bahan utamanya adalah bahan makanan sisa yang masih layak untuk diolah. Sedangkan untuk hasil pengolahan dengan teknik pengolahan kompos, output yang dihasilkan adalah berupa kompos yang dapat digunakan pada community garden dan dapat dijual ke masyarakat sekitar. Pengolahan kompos dapat menggunakan mesin, dapat juga secara manual. Untuk yang secara manual akan dijadikan bahan pembelajaran bagi pengunjung berupa pelajar/mahasiswa yang ingin belajar bagaimana cara mengolah kompos. 


\section{Implementasi Layer dalam Proyek Perancangan}

Dalam bangunan ini terdapat beberapa kegiatan diantaranya : Pasar itu sendiri yang dibagi menjadi beberapa tipe yaitu: daging dan ikan, sayuran dan buah-buahan, fresh market, dan food waste market untuk menjual barang-barang yang masih layak digunakan; kegiatan pengolahan yang mengolah sampah organik menjadi bahan yang dapat digunakan kembali; dan kegiatan komunitas bagi masyarakat sekitar. Layering pada bangunan dapat terlihat pada pembagian zona per jenis fungsinya masing-masing agar penyaluran sampah sisa nya yang akan diolah menjadi lebih teratur dan tidak tercampur karena masing-masing jenis sampah sisa tentunya menghasilkan output yang berbeda- beda.

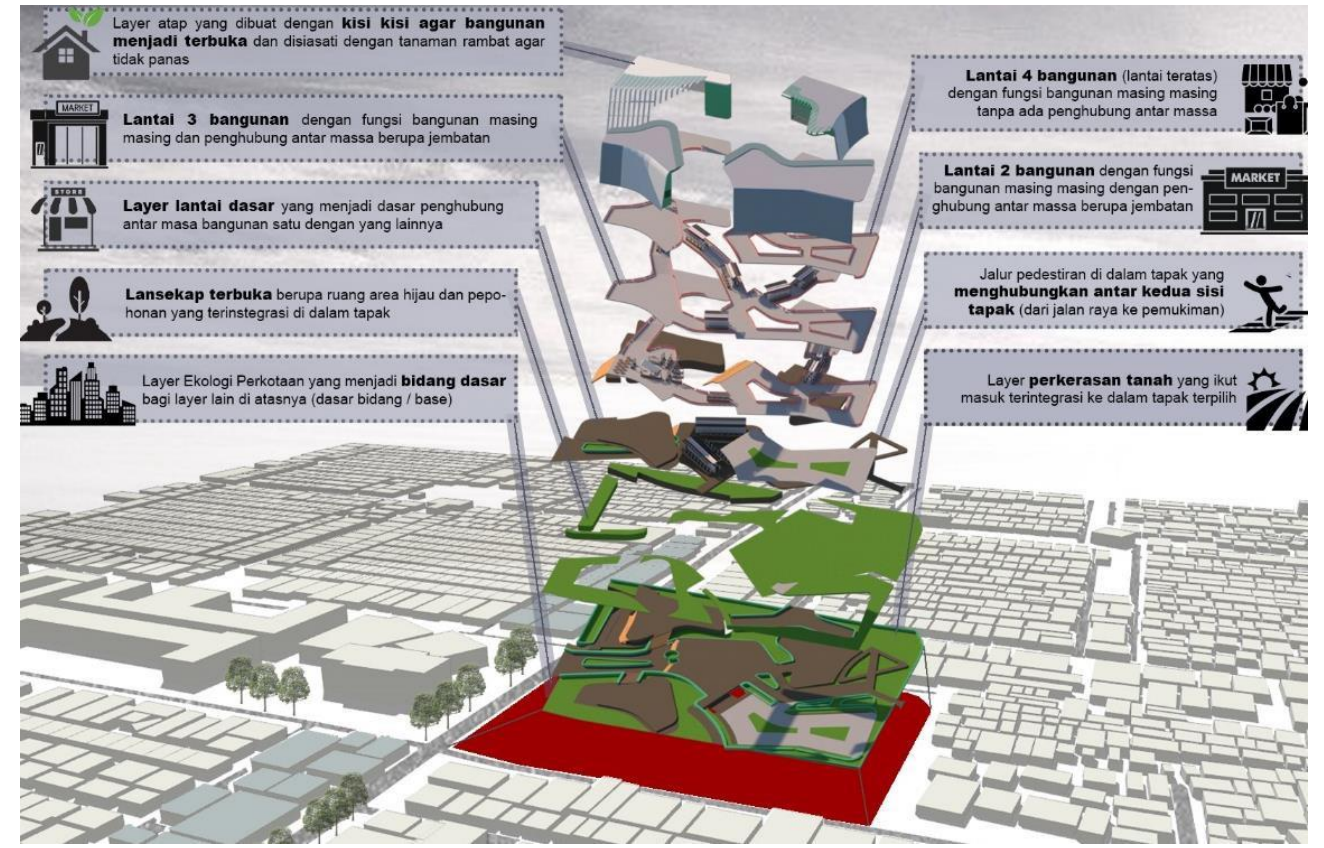

Gambar 5. Axonometry Exploded pada Proyek Perancangan

Sumber: Penulis, 2021

Area masuk disambut oleh jalur pedestrian yang nyaman bagi pengunjung yang datang dengan berjalan kaki dan paling dekat dengan area drop off dan area pasar fresh market. Selain itu, area kitchen hub dan food stall diletakkan pada bagian depan dengan harapan mempermudah akses bagi pengunjung. Kegiatan pasar daging dan ikan diletakkan di sebelah area pasar sayuran dan buah. Area pengolahan diletakkan dibagian belakang tapak agar dekat dengan pemukiman. Area komunitas juga diletakkan pada bagian belakang tapak juga agar dekat dengan masyarakat. Pada bagian tengah digunakan sebagai area kios food waste market serta area terbuka bagi pengunjung. (lih. gambar 5).

Bentuk bangunan dari pasar ini sendiri juga dibuat relatif terbuka, agar dapat menciptakan suasana pasar yang ramah lingkungan serta dapat memanfaatkan iklim alam semaksimal mungkin. Diadakan juga ruang terbuka dibagian tengah tapak agar pengunjung dapat bersosialisasi satu sama lain dan bisa menjadi tempat berkumpul bagi para pengunjung. Dapat disimpulkan bahwa indikator metode desain arsitektur hijau ini ada 4 macam yang utama, yaitu:

- Food Waste - bahan energi baru

Pada poin ini difokuskan agar bahan sampah organik/makanan sisa yang sudah tidak terpakai lagi agar bisa diolah kembali menjadi bahan energi baru. Pada proyek perancangan, bahan sampah organik/makanan ini dapat diolah kembali dengan 2 cara, yaitu dengan pengolahan biogas dan pengolahan kompos. Pada pengolahan 
biogas, dapat dihasilkan 3 jenis hasil olahan, yaitu : Cooking Fuel (Gas untuk memasak), Listrik, dan Fertilizer (pupuk untuk tanaman). Sedangkan pada pengolahan kompos, bahan sampah organik/makanan ini dapat dihasilkan kompos yang dapat digunakan kembali di community garden ataupun dapat dijual kembali ke masyarakat sekitar.

o Material ramah lingkungan

Proyek perancangan ini dirancang mengoptimalkan material yang ada dengan meminimalkan penggunaan material baru. Pada poin ini difokuskan pada material kisikisi kayu yang berada di atap bangunan.

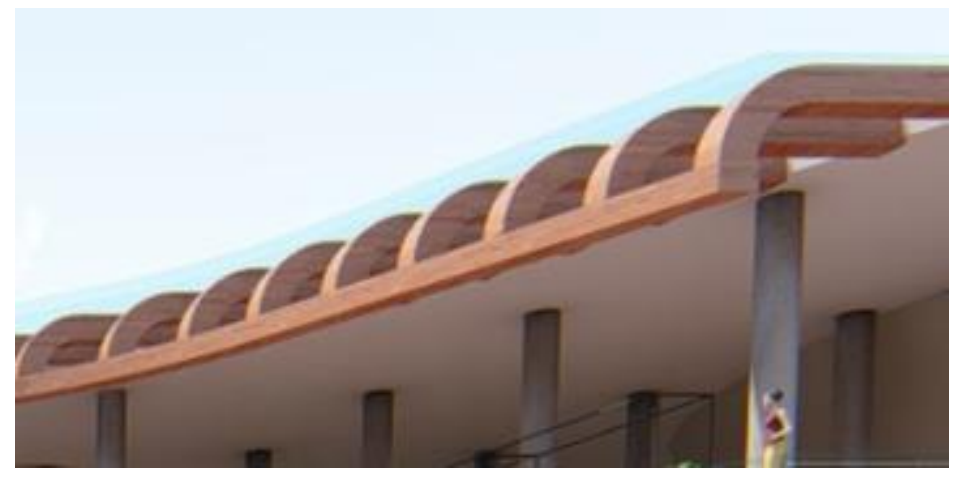

Gambar 6. Detail Kisi-Kisi Kayu pada Atap Bangunan Sumber: Penulis, 2021

Material juga harus mampu memberikan dampak positif terhadap lingkungan sekitar tapak proyek perancangan. Karena menggunakan metode perancangan arsitektur hijau, bangunan tidak boleh terdominasi oleh material yang sangat berbeda dengan bangunan sekitar, tetapi harus menyelaraskan materialnya. (lih. gambar 6).

- Memanfaatkan iklim yang ada

Bangunan memanfaatkan kondisi alam, iklim, dan lingkungannya sekitar ke dalam bentuk bangunan serta pengoperasiannya. Pada poin ini, dapat dilihat pada massa dalam proyek perancangan cenderung terbuka, agar angin dapat mengalir dengan bebas masuk ke dalam massa.

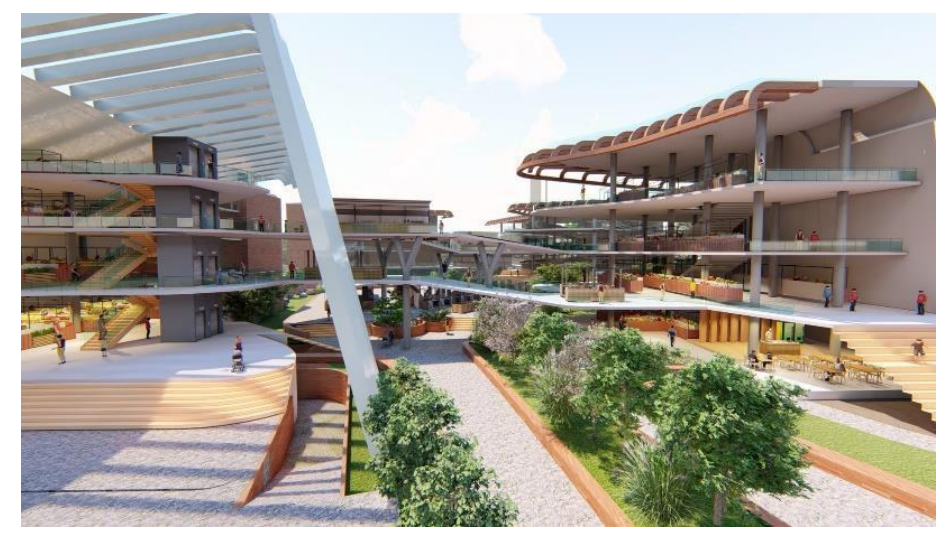

Gambar 7. Bentuk Massa Proyek Perancangan

Sumber: Penulis, 2021

Selain itu juga penggunaan kisi-kisi kayu pada atap agar sinar matahari dapat masuk langsung ke dalam bangunan dengan pembentukan bayangan/shading agar tidak 
langsung mengenai pengunjung. (lih. gambar 7).

o Pengguna yang sesuai

Kebutuhan akan green architecture harus memperhatikan kondisi pemakai yang didirikan didalam perencanaan dan pengoperasiannya. Dalam hal ini, proyek perancangan berada di Grogol Petamburan, daerah pemukiman padat penduduk. Dan Pasar Kopro ini merupakan salah satu lokasi yang dikunjungi rutin oleh mayarakat sekitar Pasar Kopro. Sehingga proyek perancangan ini harus dirancang dengan sirkulasi pasar dan pengolahan sampah yang baik, agar tidak menjadi sarang penyakit/tempat yang kumuh. Serta ruang yang cendering terbuka agar udara dapat mengalir dengan baik dan tidak menjadi pengap.

\section{KESIMPULAN DAN SARAN Kesimpulan}

Kesimpulan yang didapat dari perancangan bangunan Redesain Pasar Kopro Menjadi Pasar Berbasis Nol Sampah Makanan ini adalah sebuah bangunan yang berisikan beberapa fungsi yang sudah dikembangkan dari Pasar Kopro sebelum diredesain. Pada bangunan pasar yang belum diredesain, dapat dilihat bangunan bentuknya sangat tertutup dan tidak ada program pengolahan yang mengakibatkan sampah sisa dari pasar Kopro itu sendiri disalurkan ke TPA (Tempat Pembuangan Akhir) yang dapat memicu pemanasan global. Pada pasar yang sudah diredesain, sudah ada program pengolahan yang membuat bangunan pasar menjadi lebih berkelanjutan. Tentunya program tambahan ini dapat mendukung program utama yaitu pasar itu sendiri dan dapat digabungkan dengan aktivitas-aktivitas yang beralur sehingga dapat membentuk sistem zero food waste tersebut. Berorientasi kepada sistem sehingga menciptakan program yang erat kaitannya dengan aktivitas dan kebiasaan warga sekitar untuk memenuhi kebutuhan masyarakat sehari-hari. Mengaplikasikan konsep arsitektur hijau pada proyek perancangan ini juga tentunya dengan pertimbangan-pertimbangan sesuai dengan konsep pasar itu sendiri seperti apa. Rancangan ini juga telah memperhitungkan kebutuhan lahan pedagang dalam proyek perancangan beserta luasan-luasan kebutuhan per programnya agar dapat memenuhi kebutuhan masyarakat. Memiliki fungsii yang fleksibel dan juga edukatif sehingga tidak hanya menjadi tempat pemenuhan kebutuhan sehari-hari tetapi juga dapat memberikan edukasi bagi pengunjung pelajar/mahasiswa berupa kegiatan-kegatan seperti belajar bagaimana cara mengolah kompos secara manual dan juga dapat melihat bagaimana sampah tersebut dapat diolah menggunakan mesin dan dapat menghasilkan sesuatu yang dapat digunakan kembali.

\section{Saran}

Sebaiknya untuk pasar-pasar yang lain juga dibuat program pengolahan agar tidak banyak membuang sampah yang akan dibakar di TPA (Tempat Pembuangan Akhir) yang dapat memicu pemanasan global menjadi lebih tinggi lagi karena kandungan dari gas pembakaran sampah tersebut.

\section{REFERENSI}

Academia Edu, Pembuatan Biogas Sederhana untuk Rumah Tangga, Penerbit perkim.id. Jakarta. Dikutip pada 13 Mei 2021: https://perkim.id/permukiman/pembuatan-biogassederhana-untuk-rumah-tangga/

Adiwibowo, (2007), Bedah Buku Politics and the Environment. Jurnal Transdisiplin Sosiologi, Komunikasi, dan Ekologi Manusia, 1 (1), 162-168

Design Media Publishings Limited, (2010), Jurnal Implementasi Konsep Zero Energy Building dari Pendekatan Eco-Friendly pada Rancangan Arsitektur, (1), 3 
Erwan, A. (2008), Higienitas perspektif hadis: kajian hadis-hadis tentang kebersihan makanan, sumber air, rumah dan jalanan. Jakarta

Nasichin, K. (2010). Perancangan kembali pasar Karangploso Kabupaten Malang: Tema sustainable architecture (Doctoral dissertation, Universitas Islam Negeri Maulana Malik Ibrahim)

Neufert, E. (1980), Data Arsitek jilid 1 \& 2

Nugroho, (2012). Redesain Bangunan Publik. Jakarta.

Nugroho, (2019). Buku Pedoman Energi Efisiensi untuk Desain Bangunan Gedung di Indonesia, Jakarta: Energy Efficiency and Conservation Clearing House Indonesia.

Oktaviana, G, (2011), Landasan Konseptual Perencanaan Dan Perancangan Redesain Pasar Tradisional Jongke, Surakarta. Diss. UAJY

Sri Wahyu MP, (2008). Proses Pengolahan Biogas. Dikutip 6 Mei 2021 dari Enero.com: https://tirto.id/darurat-sampah-makanan-di-indonesia-f3Yn 